\title{
Online Teaching During COVID-19 Pandemic: The Perspectives of a Medical Teacher
}

\author{
Bindu T Nair
}

Journal of Medical Academics (2020): 10.5005/jp-journals-10070-0064

The dawn of the year 2020 has brought the world to face off with the worst reality of the millennium in the form of one of the most contagious respiratory infections caused by the novel coronavirus, named COVID-19. ${ }^{1}$ Within a short time span, the disease had acquired such a mammoth proportion that World Health Organization had to declare the coronavirus outbreak to be a pandemic on March 11, 2020. ${ }^{2}$

Subsequently, a complete lockdown was declared in India from March 25, 2020, and all educational institutions including colleges, schools, and universities were shut to ensure social distancing and thus, prevent the spread of the virus. The pandemic thus forced educational institutions all over India, and also the world over to shift to online classes. This transition has not been very smooth for most educational institutions in India especially in some fields of education like medicine where learning is incomplete without dealing with real patients. Both faculty and students were grappling with this sudden transition to online education. Most students have been left hooked on to their mobile phones and computer screens.

As soon as the COVID-19 crisis broke out in India and a lockdown was announced, most medical colleges announced the suspension of classes until March 31, 2020. Few colleges started exploring virtual platforms for online classes while they awaited further advisory from the Government of India. However, the lockdown was extended further. Most college administration thought of going digital finally and resorting to online classes. Thus, online classes served as the only panacea in this time of crisis. Online teaching became a necessity rather than an option.

Going down the history lane, India's EdTech journey began in 1994 with the launch of Educomp. Around 2010, many other EdTech start-ups entered the market focusing on the education sector. Even though many educationists worldwide have felt that online teaching is the future, it is the pandemic that has accelerated the process and led to the realization of its importance.

In the beginning, as the phenomenon of online teaching was novel yet relatively unexplored, most colleges made some investment in infrastructure for virtual platforms like Zoom, G Suite [Google Meet (formerly Hangouts Meet), Google Classroom], Microsoft Teams, etc. Luckily for most colleges, free versions of these platforms were made available for as long as 6 months. Additional training was conducted for teachers and students to get them acquainted with these platforms. ${ }^{3}$ All these virtual platforms can be accessed easily even from mobile devices. Cheaper internet data packages from various telecom companies were also made available to students.

Many students had left for their homes without carrying their textbooks. Many publishers came to their rescue by providing free access to various e-resources like e-books and also databases. Though with an initial hesitation and reluctance in a few medical

Department of Paediatrics, Army College of Medical Sciences, Delhi Cantt, New Delhi, India

Corresponding Author: Bindu T Nair, Department of Paediatrics, Army College of Medical Sciences, Delhi Cantt, New Delhi, India, Phone: +91 9958447290, e-mail: binduprakashsanjay@gmail.com

How to cite this article: Nair BT. Online Teaching During COVID-19 Pandemic: The Perspectives of a Medical Teacher. J Med Acad 2020;3(2):31-32.

Source of support: Nil

Conflict of interest: None

teachers started sending online PowerPoints, pdfs, podcasts, videos to students, and also resorted to simulation-based teaching.

Even though the initial shift to online had created a flurry amongst both students and teachers but everything settled in a few days. ${ }^{4}$ However, a problem more peculiar to medical education cropped up as clinical teaching on real patients is an inevitable part of medical education which is not possible in online teaching. Even though taking an online theory class may not be difficult but to take dissection or practical classes and clinics was a real challenge. Students struggled to understand concepts without hands-on exposure.

Online teaching is not so easy as speaking into a speaker at one end, connecting to a laptop/mobile, and listening to on the other end. There are challenges faced by both teachers as well as students. Online classes require a lot of motivation and attention. ${ }^{5}$ Students have found it difficult to focus on a pixelated video screen for long hours of online classes. Assessment on the online platform is a real challenge. Theory examinations almost translated to an open book exam that they wrote online and practical exams were in the form of online viva on simulated environment and patients.

Medical education covers a highly structured curriculum in a variety of preclinical and clinical environments. A major challenge faced by the medical teachers with online teaching is to replicate the experience of clinical exposures of OPD and wards. Medical education also involves a lot of interactions and open discussions in tutorials or small group teaching which gets lost on a virtual platform.

Direct communication with students and human interaction is missing in online teaching. The eye contact of face-to-face teaching is also not possible. The excitement and emotions palpable in a real class are missing in online classes. Most medical teachers have felt that participation by students is not enough in online classes and they have to put on considerable effort to retain their attention, increase student engagement, assess them, and take feedbacks. This may create an ineffective and meaningless learning environment. 
Medical education is not only about classes or exams. It involves experiential learning and prepares a student to become a physician of the first contact with the requisite knowledge, psychometric skills, affective, and communication skills. We have to now focus on creating a new normal. Even though a return to teaching in real ward settings is highly desirable, as of now it seems uncertain whether a typical pre-COVID-19 teaching would be possible.

The question that comes to our minds is whether conventional medical education has changed forever. Will online teaching become the future of medical education? If the pandemic continues and educational institutions remain closed, will medical education undergo a fundamental change? As we look toward the future, medical education may never come back to pre-COVID times. Our assessment and accrediting agencies will also have to join in the adaptation.

As we reflect on the COVID-19 pandemic, there is a worry among medical educators about the cascading effect of online teaching. The profound effects of the pandemic may forever change the way future doctors are educated. We may be facing a looming new normal which will transform conventional medical education. The way ahead is to incorporate all the lessons learned so far from the present online teaching and evolve a methodology adopting the best practices of both the end of the spectrum.

\section{References}

1. Coronavirus Disease 2019 (COVID-19). https://www.cdc.gov/media/ $\mathrm{dpk} /$ diseases-and-conditions/coronavirus/coronavirus-2020.html (Accessed on 01 September, 2020).

2. WHO Director-General's opening remarks at the Mission briefing on COVID-19-12 March 2020. https://www.who.int/dg/speeches/detail/ who-director-general-s-opening-remarks-at-the-mission-briefingon-covid-19---12-march-2020 (Accessed on 05 September, 2020).

3. Nimrod G. Technophobia among older internet users. Educ Gerontol 2018;44(2-3):148-162. DOI: 10.1080/03601277.2018.1428145.

4. Esani M. Moving from face-to-face to online teaching. Clin Lab Sci 2010;23(3):187-190. DOI: 10.29074/ascls.23.3.187.

5. Maheshwari S, Zheleva B, Rajasekhar V, et al. e-Teaching in pediatric cardiology: a paradigm shift. Ann Pediatr Cardiol 2015;8(1):10-13. DOI: 10.4103/0974-2069.149512. 